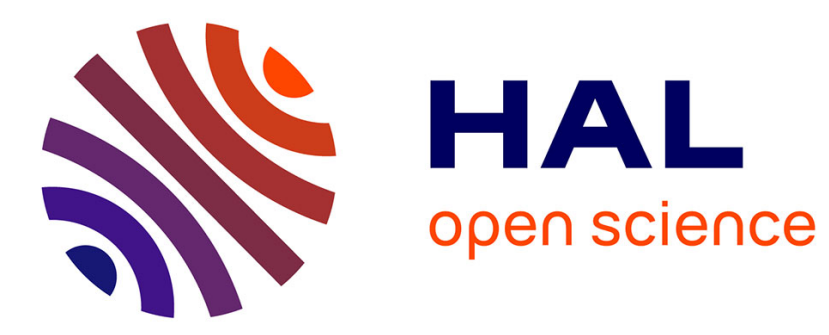

\title{
Combustion synthesis of TiC-based ceramic-metal composites with high entropy alloy binder
}

A.S. Rogachev, S.G. Vadchenko, N.A. Kochetov, D. Yu. Kovalev, I.D. Kovalev, A.S. Shchukin, A.N. Gryadunov, Florence Baras, O. Politano

\section{To cite this version:}

A.S. Rogachev, S.G. Vadchenko, N.A. Kochetov, D. Yu. Kovalev, I.D. Kovalev, et al.. Combustion synthesis of TiC-based ceramic-metal composites with high entropy alloy binder. Journal of the European Ceramic Society, 2020, 10.1016/j.jeurceramsoc.2019.11.059 hal-02381366

\section{HAL Id: hal-02381366 https://hal.science/hal-02381366}

Submitted on 10 Nov 2020

HAL is a multi-disciplinary open access archive for the deposit and dissemination of scientific research documents, whether they are published or not. The documents may come from teaching and research institutions in France or abroad, or from public or private research centers.
L'archive ouverte pluridisciplinaire HAL, est destinée au dépôt et à la diffusion de documents scientifiques de niveau recherche, publiés ou non, émanant des établissements d'enseignement et de recherche français ou étrangers, des laboratoires publics ou privés. 


\title{
Combustion synthesis of TiC-based ceramic-metal composites with high entropy alloy binder
}

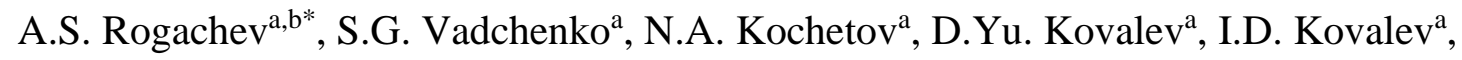
A.S. Shchukin ${ }^{\mathrm{a}}$, A.N. Gryadunov ${ }^{\mathrm{a}}$, F. Baras ${ }^{\mathrm{c}}$, O. Politano ${ }^{\mathrm{c}}$

${ }^{a}$ Merzhanov Institute of Structural Macrokinetics and Materials Science Russian Academy of Sciences (ISMAN), Academician Osipyan str. 8, Chernogolovka, Moscow Region, 142432, Russia

${ }^{b}$ National University of Science and Technology "MISIS", Leninsky prosp. 4, Moscow, 119049, Russia

${ }^{c}$ UMR 6303 CNRS-Université Bourgogne Franche-Comté, 9 Av. Alain Savary, BP 47870, 21078 Dijon Cedex, France

*Corresponding author, e-mail: rogachev@ism.ac.ru

\begin{abstract}
Ceramic-metal composites TiC-High-Entropy Alloy (HEA) CoCrFeNiMe (Me = Mn, Ti or Al) were first produced by combustion synthesis method. Self-sustained synthesis occurs due to heat release from exothermic reaction $\mathrm{Ti}+\mathrm{C}=\mathrm{TiC}$; the binder content was varied between zero and 40-50 wt. $\%$. The combustion velocity and temperature gradually decreased with increasing binder content. Resultant materials consist of TiC grains and two-phase $(f c c$ and $b c c)$ binder. Vickers microhardness (100 g) of compacted cermet materials with 30 wt.\% of binder was in the range of 10-17 GPa and increased with increasing $b c c$ to $f c c$ ratio. Based on experimental results and thermodynamic calculations, the mechanism of microstructure formation in TiC-HEA cermets was suggested.
\end{abstract}

Keywords: cermet, titanium carbide, high-entropy alloy, structure, electron microscopy

\section{Introduction}

Ceramic-metal composites (cermets) have found wide application due to unique combination of the ceramic and metal alloy properties. Among these, carbide-based 
materials, often named cemented carbides, are widely used as wear-resistant materials, cutting tools, high-temperature structural materials, etc. [1-3]. Cemented carbides consist of hard carbide grains and a ductile metal binder such as $\mathrm{WC}-\mathrm{Co}, \mathrm{TiC}-\mathrm{Ni}(\mathrm{Mo})$, TiCN-Ni. Currently, conventional WC-Co cemented carbides are gradually substituted by TiC-based [2] and TiCN-based [3] cermets with much better oxidation resistance and high-temperature strength. However, TiC-based materials are more brittle at low temperature, as compared to WC-based cermets, which inspires search for new compositions of ceramic grains and metal binders. A promising research direction is the use of recently developed high-entropy alloys (HEA), multicomponent metallic compositions that form single-phase $f c c$ or $b c c$ solid solutions [4-6]. For example, the CoCrFeMnNi alloy [7] showed excellent fracture resistance even at cryogenic temperatures $[8,9]$. Using HEA binders, several cermet materials have been obtained, including WC-CoCrFeNiMn [10], Ti(C,N)-CoCrFeNiAl [11, 12], TiB ${ }_{2}-\mathrm{CoCrFeNiTiAl}$ [13, 14], $\mathrm{TiB}_{2}-\mathrm{CoCrFeNiAl} \mathrm{[15],} \mathrm{and} \mathrm{TiB}_{2}-\mathrm{TiC}-\mathrm{CoCrFeNiTiAl} \mathrm{[15].} \mathrm{It} \mathrm{was} \mathrm{suggested}$ that such materials gave birth to a new family of cermets [17].

Production of the above ceramic-HEA composites usually involves three stages: (a) mechanical alloying of elemental metal powders leading to formation of single-phase HEA powder, (b) mixing of this powder with ceramic powder, and (c) consolidation of the material (mostly by spark plasma sintering). Combustion synthesis (CS), also known as self-propagating high-temperature synthesis (SHS), is a facile method for production of TiC-based cermets [18-20]. The material can be synthesized in an SHS mode due to extremely high thermal effect of the reaction: $\mathrm{Ti}+\mathrm{C}=\mathrm{TiC}+310 \mathrm{~kJ} / \mathrm{mol}$. The heat released during the reaction rises the temperature up to $3290 \mathrm{~K}$, which afford for the addition of up to $50-60$ wt. $\%$ of inert metal binder such as $\mathrm{Ni}: \mathrm{Ti}+\mathrm{C}+\mathrm{Ni}=\mathrm{TiC}+\mathrm{Ni}$ 
[21]. The binder does not react and therefore decreases the product temperature.

However, reaction occurs in a self-sustained mode until the temperature drops below the melting point of $\mathrm{Ti}(1940 \mathrm{~K})$. Recently, we have shown that the cermet consisting of 70 wt.\% TiC and 30 wt.\% CoCrFeNiMn HEA binder can be produced by combining SHS with hot pressing $[22,23]$.

In the present work, we investigated the possibility of combustion synthesis of the TiC-HEA cermet with different contents of three binders: CoCrFeNiMn, CoCrFeNiTi, and CoCrFeNiAl.

\section{Experimental}

Commercially available powders (all Russian grades, "POLEMA” Joint Stock Company) of Ti (PTM grade, purity > 99\%, particle size $d<100 \mu \mathrm{m})$, Co (PK-1 grade, $>99.35 \%, d<71 \mu \mathrm{m}), \mathrm{Cr}(\mathrm{PCh}-1 \mathrm{M}$ grade, $>98.5 \%, d<125 \mu \mathrm{m}), \mathrm{Fe}(\mathrm{R}-10$ grade, $>97 \%$, size range 1.5-3.5 $\mu \mathrm{m}), \mathrm{Ni}(\mathrm{PNE}-1$ grade, $>99.5 \%, \mathrm{~d} \sim 3 \mu \mathrm{m}), \mathrm{Mn}(>99.7 \%, d<$ $400 \mu \mathrm{m}), \mathrm{Al}(\mathrm{ASD}-4$ grade, $>99 \%)$, and carbon black $(\mathrm{P}-803,<2 \mu \mathrm{m})$ were mixed in a mortar according to the following stoichiometry:

$$
x(\mathrm{Ti}+\mathrm{C})+(1-x)(\mathrm{Co}+\mathrm{Cr}+\mathrm{Fe}+\mathrm{Ni}+\mathrm{Me})=x \mathrm{TiC}+(1-x) \mathrm{CoCrFeNiMe}
$$

where $M e=\mathrm{Mn}$, Ti or Al, and $x$ gradually decreased from 1.0 down to the combustibility limit. Taking into account the atomic weights of the elements, mass fraction of $\mathrm{CoCrFeNiMe}$ binder $\left(m_{\mathrm{b}}\right)$ was calculated as

$$
m_{\mathrm{b}}=\frac{\left(225.47+A_{M e}\right)(1-x)}{225.47+A_{M} e^{-\left(165.47+A_{M e}\right) x}} \cdot 100 \%
$$

where $A_{M e}$ is the atomic weight of $M e$. The powder mixtures were cold-pressed into cylindrical pellets for use in combustion and consolidation experiments. 
Two types of the experiments were carried out. Possibility of self-sustained synthesis and velocity of the combustion wave propagation were studied using the samples $10 \mathrm{~mm}$ in diameter, $15 \mathrm{~mm}$ high, and $40 \%$ porosity. The samples were placed vertically in a closed reaction chamber in an Ar atmosphere (0.12 $\mathrm{MPa})$, and the reaction was initiated with an electrically heated tungsten wire from the top. The reaction front propagated downward and the process was video recorded through a refractory glass window. The wave propagation velocity was derived from saved video files. For the consolidation of materials a quasi-static SHS pressing method was applied $[18,21]$. The sample with diameter $30 \mathrm{~mm}$, height $10 \mathrm{~mm}$ and porosity $40 \%$ was placed in a steel mold filled with bank sand to protect the mold walls from direct contact with hot reaction products and to transfer pressure from the die punch to the sample. The reaction was initiated by hot $\mathrm{W}$ wire under a pressure of $10 \mathrm{MPa}$ held for $2 \mathrm{~s}$, after which the pressure was raised to $100 \mathrm{MPa}$ and kept on for 3-5 s. The combustion wave propagated horizontally across the disk-shaped sample, while the pressure was applied vertically.

The X-ray diffraction analysis was performed with a DRON-3M diffractometer (Russia). The SEM and EDS studies were made using a Zeiss Ultra Plus field-emission scanning electron microscope (Carl Zeiss, Germany) equipped with an energy dispersive spectrometer INCA Energy 350 XT (Oxford Instruments, UK). Microhardness was measured with a PMT3 tester (Russia) under $100 \mathrm{~g}$ load. Thermodynamic calculations were performed using THERMO and THERMO-CALC software with TCHEA3 database.

\section{Results}


Self-sustained mode of combustion synthesis was found to be possible for the HEA binder content from zero up to 45-60 wt.\% (Fig. 1). Both adiabatic temperature and burning velocity decreased with increasing $m_{\mathrm{b}}$. Such dependences are expectable because only the reaction $\mathrm{Ti}+\mathrm{C}$ has strong exothermic effect, i.e., generates heat, while alloying of the HEA binder from elements does not produce notable heat release. When the adiabatic temperature decreases below the melting point of $\mathrm{Ti}$, self-propagating synthesis becomes impossible. This limit occurs at $m_{\mathrm{b}}=55 \mathrm{wt} . \%$ for the CoCrFeNiMn binder, at 60 wt. $\%$ for $\mathrm{CoCrFeNiTi}$, and at 45 wt. \% for $\mathrm{CoCrFeNiAl}$. The combustion becomes unsteady, oscillating or spinning, in the vicinity of the combustibility limits (dashed lines in Fig. 1).

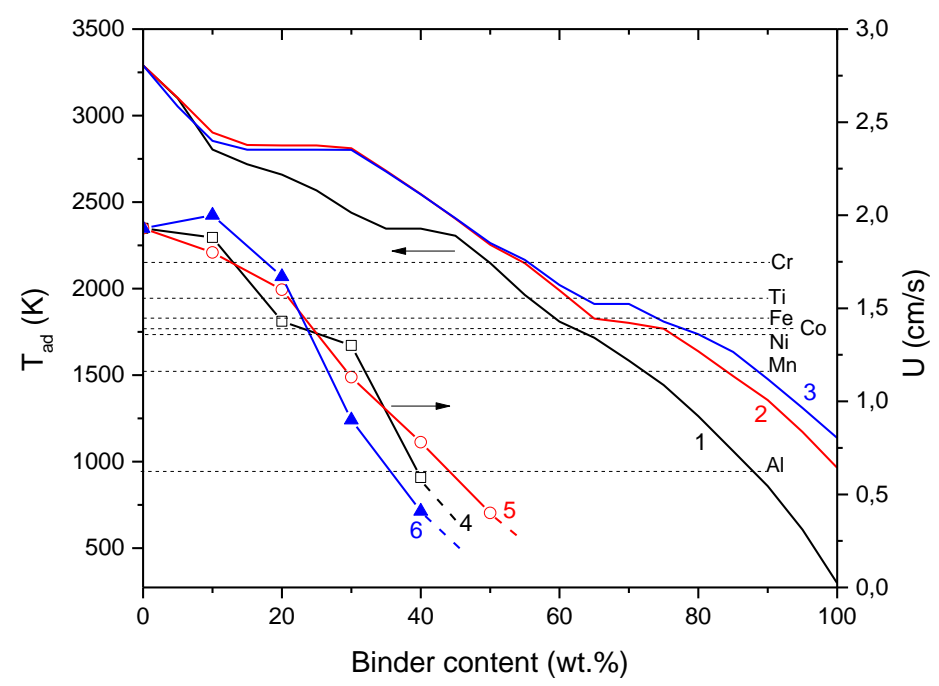

Fig. 1. Calculated adiabatic combustion temperatures (1-3) and measured burning velocities (4-6) for TiC-HEA systems with different HEA binders: CoCrFeNiMn $(1,4)$, CoCrFeNiTi $(2,5)$, and $\mathrm{CoCrFeNiAl}(3,6)$. The horizontal dashed lines show the melting temperatures of starting reagents. 
The XRD results demonstrate that $\mathrm{TiC}$ is the main product phase for all compositions and binder contents (Fig. 2). Analysis of the XRD patterns showed (Table 1) that the lattice parameter of B1 major cubic phase (NaCl-type) weakly depends on binder content, and correlates with the lattice parameters of $\operatorname{TiC}_{x}(x=0.68-0.98)$ that are in the range of 4.3198-4.3258 $\AA$ [24]. Diffraction peaks of two metallic alloy phases, with $b c c$ and $f c c$ crystal structures, were detected along with the peaks of TiC. The lattice parameters for these phases were evaluated roughly, because of broadening and relatively low peak intensities. The $b c c$ phase has the major diffraction peak (110) at $44.5^{\circ}$, while the major peak (111) of the $f c c$ phase can be observed in the range of $43.4^{\circ}-43.8^{\circ}$
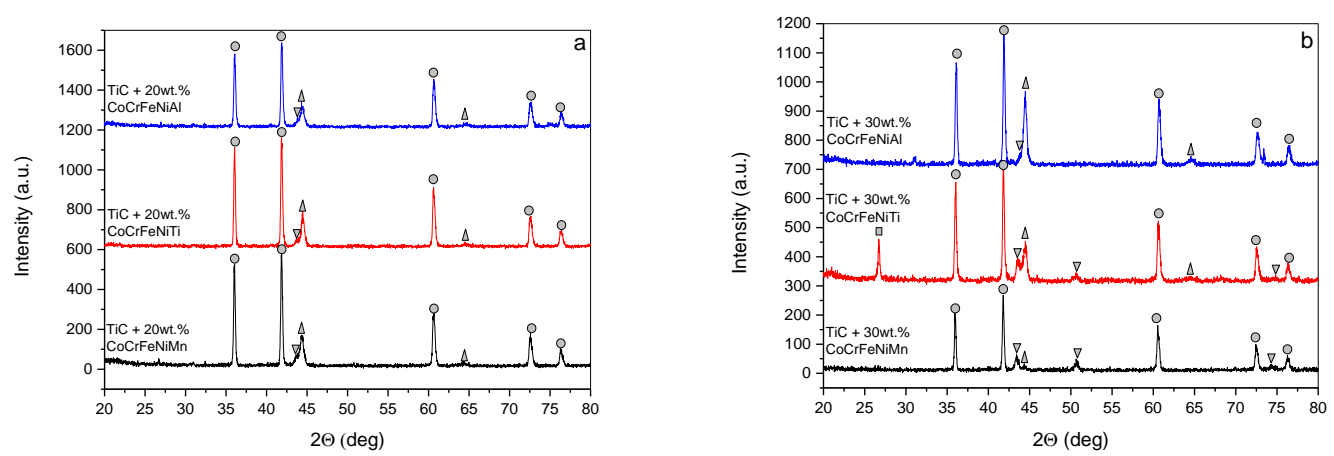

Fig. 2. X-ray diffraction patterns of the samples with $20 \mathrm{wt} . \%$ (a) and $30 \mathrm{wt} . \%$ (b) of HEA binders: TiC $(\bigcirc), b c c$ phase $(\triangle), f c c$ phase $(\nabla)$, unidentified peak ( $(\square$ ).

In order to estimate the relative amounts of $b c c$ and $f c c$ phases, the following parameter was used:

$$
k=\frac{I_{f c c}}{I_{b c c}+I_{f c c}}
$$


where $I_{f c c}$ is intensity of the (111) peak of the $f c c$ phase, and $I_{b c c}$ is intensity of the (110) peak of the bcc phase. As shown in Table 1, this parameter depends on binder content. Thus, in the TiC-CoCrFeNiMn cermet the amount of the $f c c$ phase reaches its maximum when the material contains $30 \mathrm{wt} . \%$ of the binder.

An unidentified peak was observed at $26.7^{\circ}$ in the samples $\mathrm{TiC}-\mathrm{CoCrFeNiTi}$ containing $30 \mathrm{wt} . \%$ and more HEA binder. A d-spacing corresponding to this peak (3.34 $\AA$ ) correlates with the line (002) of graphite. Therefore, we can guess that some carbon remained unreacted in the samples with high binder content and low combustion temperature, however, one XRD peak is not enough to identify the phase. This peak was not observed in the samples with other HEA composition or in the samples containing less than 30 wt.\% of the CoCrFeNiTi.

Table 1. Results of XRD analysis: crystal lattice parameters $(d)$ and ratio $k$ of the $f c c$ to $b c c$ phase as a function of binder composition and mass fraction.

\begin{tabular}{|c|c|c|c|c|c|c|c|c|}
\hline \multirow[t]{2}{*}{ Composition } & \multirow[t]{2}{*}{ Parameter } & \multicolumn{7}{|c|}{ HEA binder (wt. \%) } \\
\hline & & 0 & 10 & 20 & 30 & 40 & 50 & 60 \\
\hline \multirow{4}{*}{$\begin{array}{l}\mathrm{TiC}+ \\
\mathrm{CoCrFeNiMn}\end{array}$} & $d_{\mathrm{TiC}}(\AA)$ & 4.324 & 4.321 & 4.320 & 4.322 & 4.322 & 4.319 & - \\
\hline & $d_{\mathrm{fcc}}(\AA)$ & - & 3.608 & 3.593 & 3.607 & 3.608 & 3.591 & - \\
\hline & $d_{\mathrm{bcc}}(\AA)$ & - & 2.893 & 2.886 & 2.887 & 2.887 & 2.875 & - \\
\hline & $k$ & - & 0.175 & 0.287 & 0.713 & 0.321 & 0.478 & - \\
\hline \multirow{4}{*}{$\begin{array}{l}\mathrm{TiC}+ \\
\mathrm{CoCrFeNiTi}\end{array}$} & $d_{\mathrm{TiC}}(\AA)$ & 4.324 & 4.320 & 4.320 & 4.320 & 4.323 & 4.319 & 4.316 \\
\hline & $d_{\mathrm{fcc}}(\AA)$ & - & 3.613 & 3.582 & 3.596 & 3.590 & 3.579 & 3.621 \\
\hline & $d_{\mathrm{bcc}}(\AA)$ & - & 2.881 & 2.880 & 2.878 & 2.877 & 2.872 & 2.936 \\
\hline & $K$ & - & 0.195 & 0.214 & 0.383 & 0.438 & 0.525 & 0.455 \\
\hline \multirow{4}{*}{$\begin{array}{l}\mathrm{TiC}+ \\
\mathrm{CoCrFeNiAl}\end{array}$} & $d_{\mathrm{TiC}}(\AA)$ & 4.324 & 4.321 & 4.318 & 4.316 & 4.316 & - & - \\
\hline & $d_{\mathrm{fcc}}(\AA)$ & - & 3.582 & 3.574 & 3.576 & 3.574 & - & - \\
\hline & $d_{\mathrm{bcc}}(\AA)$ & - & 2.875 & 2.881 & 2.878 & 2.881 & - & - \\
\hline & $k$ & - & 0.224 & 0.375 & 0.173 & 0.213 & - & - \\
\hline
\end{tabular}

SEM observations have confirmed that the synthesized materials consist of rounded TiC grains and a metal binder (Fig. 3). Grain size decreased with increasing binder 
content. The material with a CoCrFeNiTi binder exhibited larger grain size than those containing similar amount of $\mathrm{CoCrFeNiMn}$ or $\mathrm{CoCrFeNiAl}$ binders. The elemental distributions are presented in Fig. 4.

Based on the results of combustion experiments and structural analysis, a composition of $70 \mathrm{wt} . \% \mathrm{TiC}+30 \mathrm{wt} . \% \mathrm{HEA}$ was selected to produce compact materials. After combustion synthesis and quasi-isostatic hot pressing, the samples were cut with diamond saw, polished, and used in hardness measurements. The Vickers microhardness values of pore-free materials are presented in Table 2.

Table 2. Microhardness of the consolidated materials.

\begin{tabular}{|l|c|}
\hline Composition & $\begin{array}{c}\text { The Vickers microhardness } \\
\text { (GPa) }\end{array}$ \\
\hline 70 wt.\%TiC -30 wt.\%CoCrFeNiMn & $10.6 \pm 2.5$ \\
\hline 70 wt.\%TiC -30 wt.\%CoCrFeNiTi & $15.1 \pm 3.6$ \\
\hline 70 wt.\%TiC -30 wt.\%CoCrFeNiAl & $17.7 \pm 3.3$ \\
\hline
\end{tabular}

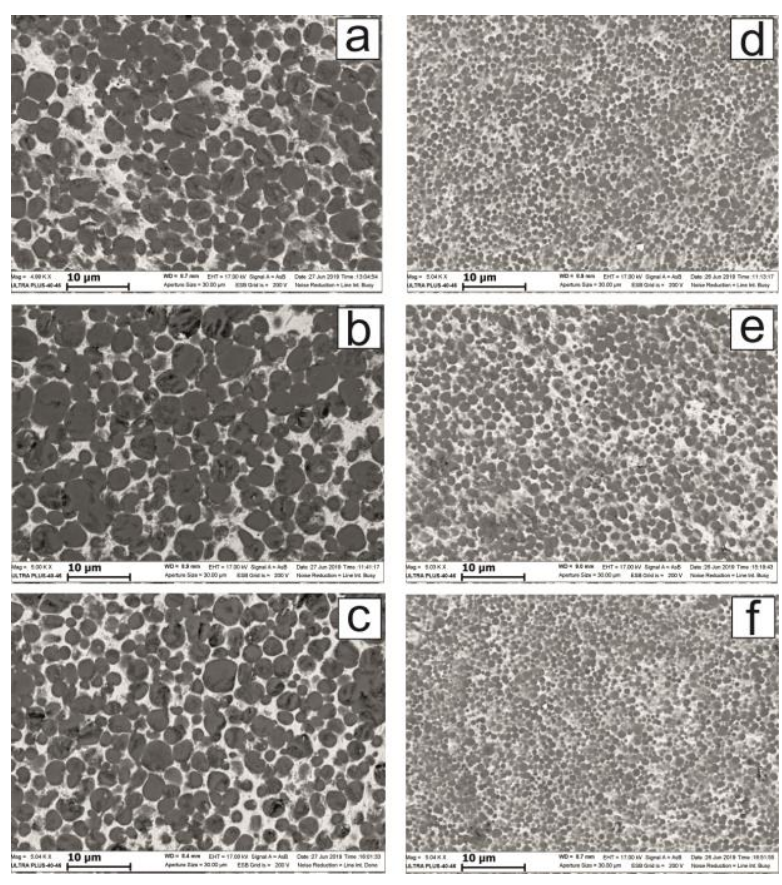


Fig. 3. BSE SEM images of synthesized $\mathrm{TiC}-\mathrm{CoCrFeNiMn}(\mathrm{a}, \mathrm{d}), \mathrm{TiC}-\mathrm{CoCrFeNiTi}(b$, e), and TiC-CoCrFeNiAl (c, f) cermets. Binder content: 20 wt.\% (a, b, c) and 40 wt.\% (d, e, f); TiC grains are shown in dark gray while HEA binder, in light gray.

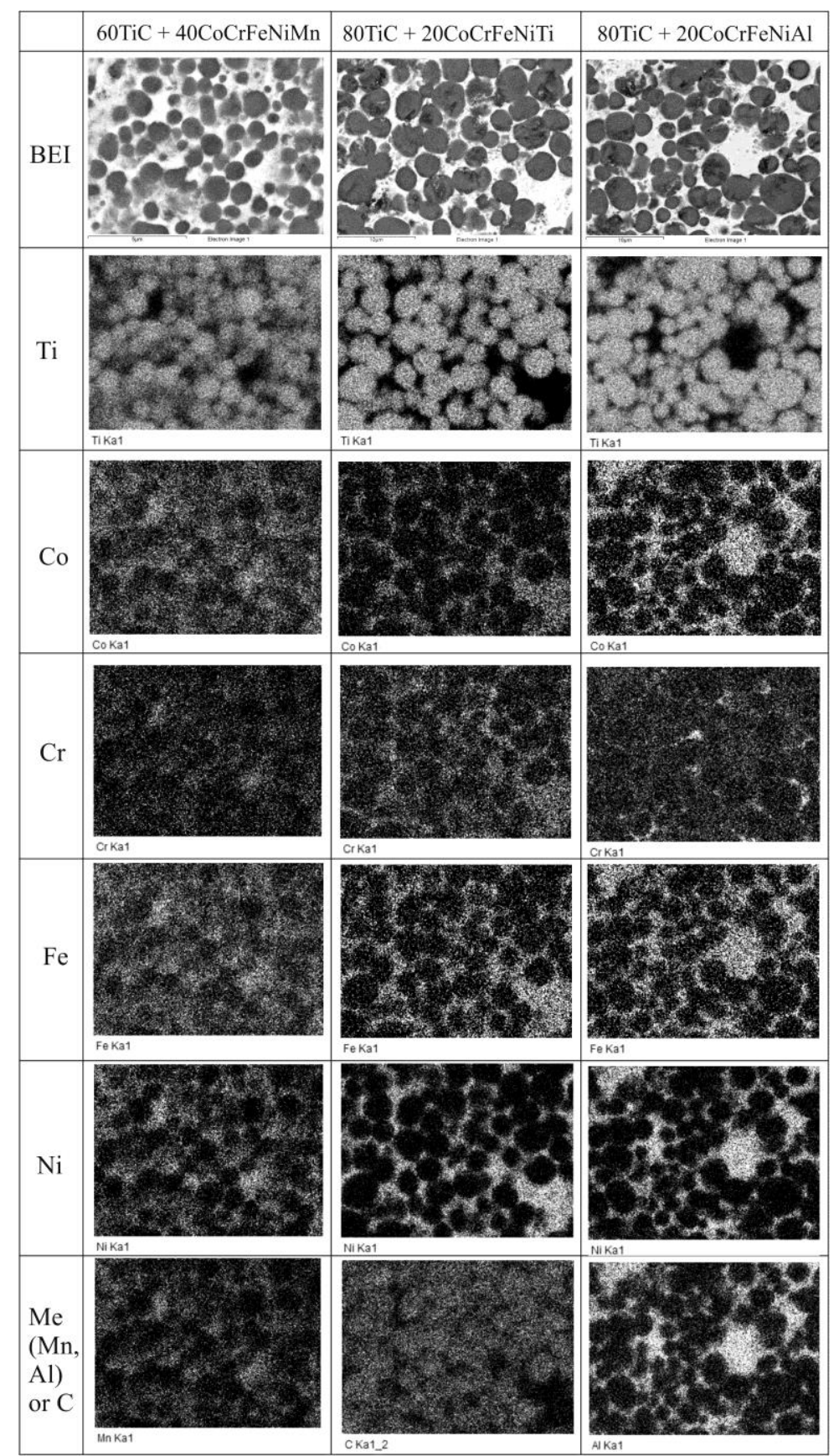

Fig. 4. EDS analyses of synthesized materials. More data are presented in supplementary file $\mathrm{S} 1$. 


\section{Discussion}

Since the starting mixtures contained 6 or 7 elemental powders, we could expect the formation of several intermetallic phases such as NiAl, TiAl, TiNi, TiMn, etc., as well as a variety of carbides such as $\mathrm{TiC}, \mathrm{Cr}_{3} \mathrm{C}_{2}, \mathrm{Mn}_{7} \mathrm{C}_{3}, \mathrm{Fe}_{3} \mathrm{C}$, and ternary phases. However, our thermodynamic calculations and experimental results clearly show that TiC appears as a major phase in all of synthesized materials along with two simple solid solutions ( $f c c$ and $b c c$ phases). Evidently, this is due to very strong chemical bonding between $\mathrm{Ti}$ and $\mathrm{C}$, high enthalpy of formation from elements, and high temperature of the TiC crystallization. In a mode of combustion synthesis, adiabatic combustion temperature exceeds the melting points of all metallic components (Fig. 1). Hence the mechanism of material synthesis must involves three stages, as illustrated in Fig. 5. First, all metallic components melt when the temperature in the combustion wave exceeds their melting points and form the $\mathrm{Ti}-\mathrm{Co}-\mathrm{Cr}-\mathrm{Fe}-\mathrm{Ni}-\mathrm{Me}$ multicomponent melt surrounded by solid carbon particles. During the second stage, carbon dissolves in the melt and crystalline TiC grains precipitate and grow in the molten matrix. Finally, crystallization of the HEA binder occurs, when the sample temperature decreases below the melting point of the HEA. 


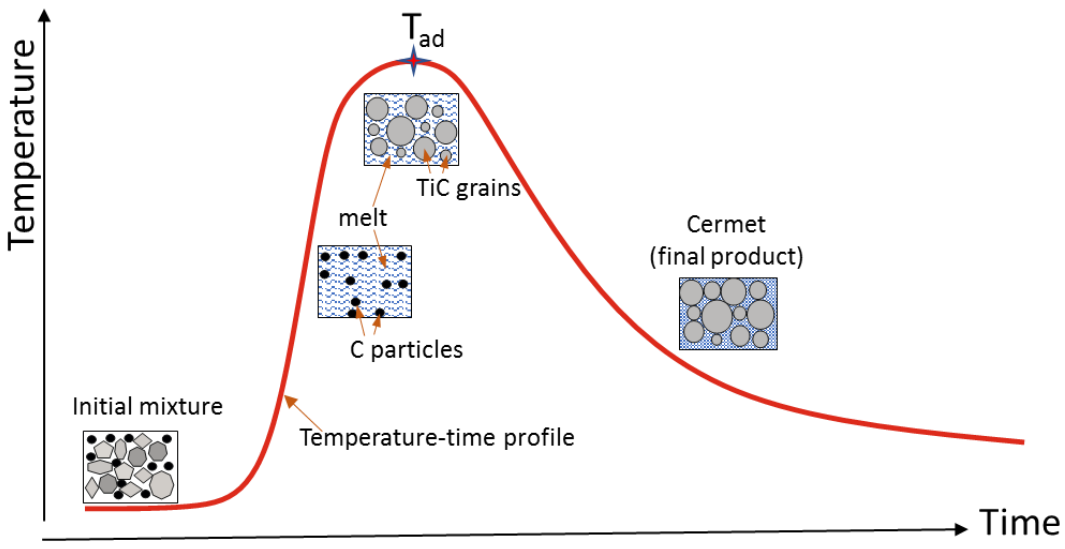

Fig. 5. Temperature-time scheme of cermet formation during combustion synthesis.

As it was shown earlier for the $\mathrm{TiC}-\mathrm{Ni}$ and $\mathrm{TiC}-\mathrm{Ni}-\mathrm{Cr}$ cermets [21], the primary $\mathrm{TiC}$ grains precipitated from the melt are very small $(<1 \mu \mathrm{m})$ but they grow behind the combustion front due to collective recrystallization: smaller grains dissolve into the melt and precipitate on the surface of larger grains (Ostwald ripening). Thus, the final grain size depends on the temperature and the melt composition. Since temperature decreases with increasing binder content (Fig. 1), the materials containing $40 \mathrm{wt} . \%$ of the binder have finer grains than the materials with $20 \mathrm{wt} . \%$ (Fig. 3, Fig. 4, and supplementary file $\mathrm{S} 1)$. We also can see that the $\mathrm{TiC}$ grains size slightly larger in the $\mathrm{TiC}-\mathrm{CoCrFeNiTi}$ cermet, as compared to $\mathrm{TiC}-\mathrm{CoCrFeNiMn}$ or $\mathrm{TiC}-\mathrm{CoCrFeNiAl}$, with the same binder content (Fig. 3). Probably, this is because increased concentration of Ti in the multicomponent melt promotes carbon dissolution and mass transfer in the molten phase.

Crystallization of $\mathrm{TiC}$ happens around $3500 \mathrm{~K}$, i.e. much above the melting points of all metallic components (most refractory of them $\mathrm{Cr}$ melts at $2150 \mathrm{~K}$ ), intermetallics ( $\mathrm{NiAl}$ at $1910 \mathrm{~K}$, TiNi at $1583 \mathrm{~K}$, etc.), other carbides (e.g., $\mathrm{Cr}_{3} \mathrm{C}_{2}$ at 2168 $\mathrm{K}, \mathrm{Fe}_{3} \mathrm{C}$ at $1923 \mathrm{~K}$ ) and present HEA. For example, the experimentally determined 
melting point of CoCrFeNiMn alloy was reported as $1607 \mathrm{~K}[25,26], 1523 \mathrm{~K}$ [27] or $1543 \mathrm{~K}$ [28], while the atomistic model calculations gave $1679 \mathrm{~K}$ [29]. Therefore, the immediate product of combustion synthesis that exists behind the combustion front in the range between $T_{\text {ad }}=3290-2250 \mathrm{~K}$, depending on binder content (Fig. 1) and 1500$1600 \mathrm{~K}$ when the HEA binder crystallizes, is TiC+melt, because during this period, only one crystalline phase, TiC, can exist. The solubilities of $\mathrm{Ni}, \mathrm{Fe}, \mathrm{Co}$, or $\mathrm{Mn}$ in solid $\mathrm{TiC}$ are negligibly low, only $\mathrm{Cr}$ can form solid solutions and binary carbide $(\mathrm{Ti}, \mathrm{Cr}) \mathrm{C}$, and $\mathrm{Al}$ can form ternary MAX-phases $\mathrm{Ti}_{3} \mathrm{AlC}_{2}$ and $\mathrm{Ti}_{2} \mathrm{AlC}$. However, the results of EDS analysis have shown that the concentration of $\mathrm{Cr}$ in the $\mathrm{TiC}$ grains is commonly below 1 at.\%. We also did not detect ternary phases such as $\mathrm{Ti}_{3} \mathrm{AlC}_{2}$. Thus, after precipitation of solid TiC grains, chemical composition of the melt should be close to the composition of respective HEA. When the melt temperature decreases, due to heat losses, down to the melting point, crystalline HEA phase appears. This process is similar to a widely used method for production HEAs from the melts, although we don't observe any dendrites that are very common in HEAs elaborated by cooling from a melt $[30,31]$. A difference is that in our case the melt appears in exothermic chemical reaction. The results of our thermodynamic calculations for the $\mathrm{Co}-\mathrm{Cr}-\mathrm{Fe}-\mathrm{Ni}-\mathrm{Mn}$ system show that a sole solid phase that appears as a result of the melt crystallization at $1600 \mathrm{~K}$ is the disordered $f c c$ (L12) HEA solid solution. The formation of other phases, including ordered and disordered $b c c$ solid solutions and intermetallics (sigma-phases) becomes thermodynamically possible at temperatures below $1100 \mathrm{~K}$ (in the Ti-C-Co-Cr-Fe-NiMn system, small amount of $\mathrm{Cr}_{0.6} \mathrm{Mn}_{0.1} \mathrm{C}_{0.3}$ can also precipitate together with the $f c c$ HEA phase). Similar calculations for the $\mathrm{Co}-\mathrm{Cr}-\mathrm{Fe}-\mathrm{Ni}-\mathrm{Al}$ system have shown that disordered $f c c$ and ordered $b c c$ phases precipitate from the melt simultaneously. These 
results are in reasonable agreement with experimental data (Fig. 2, Table 1) showing that a maximum concentration of the fcc-phase is observed for the $\mathrm{TiC}-\mathrm{CoCrFeNiMn}$ material, while the $b c c$ binder prevails in the $\mathrm{TiC}-\mathrm{CoCrFeNiAl}$ cermet. It is known that the $b c c$ phases have higher strength but lower ductility as compared to the $f c c$ ones [31] Therefore, an increase of cermet hardness from $\mathrm{TiC}-\mathrm{CoCrFeNiMn}$ through $\mathrm{TiC}-$ CoCrFeNiTi to $\mathrm{TiC}-\mathrm{CoCrFeNiAl}$ (Table 2) can be attributed to a growth in relative amount of $b c c$ phase in the cermet binders.

The nonoccurence of MAX-phases Ti3AlC2 and Ti2AlC in the TiC$\mathrm{CoCrFeNiAl} \mathrm{cermets} \mathrm{can} \mathrm{be} \mathrm{attributed} \mathrm{to} \mathrm{the} \mathrm{very} \mathrm{strong} \mathrm{chemical} \mathrm{bond} \mathrm{between} \mathrm{Ti}$ and $\mathrm{C}$, which is much stronger that the bond between $\mathrm{Ti}$ and $\mathrm{Al}$. Thus, combustion synthesis in the powder mixtures $(\mathrm{Ti}+\mathrm{C})+x \mathrm{Al}$, where $x=10 \mathrm{wt} . \%-60 \mathrm{wt} . \%$, resulted in formation of $\mathrm{TiC}$ as the only product compound, while $\mathrm{Al}$ remained as a metal binder in the final product [32]. When the powders were mixed by atomic ratios Ti:C:Al = 2:1:1, a multiphase product composed of $\mathrm{Ti}_{2} \mathrm{AlC}, \mathrm{Ti}_{3} \mathrm{AlC}_{2}$, and $\mathrm{TiC}$ was obtained after combustion synthesis [33]. The process involved three stages: (1) $\mathrm{Ti}+\mathrm{C}=\mathrm{TiC}$; (2) 2TiC $+\mathrm{Al}+\mathrm{Ti}=\mathrm{Ti}_{3} \mathrm{AlC}_{2}$; and (3) $\mathrm{TiC}+\mathrm{Al}+\mathrm{Ti}=\mathrm{Ti}_{2} \mathrm{AlC}$. Therefore, addition of $\mathrm{Al}$ to the $\mathrm{Ti}+\mathrm{C}$ mixture $(\mathrm{Ti}: \mathrm{C}=1: 1)$ is not enough to form MAX-phases, because excess of $\mathrm{Ti}$ is also required. A time-resolved synchrotron diffraction study of combustion synthesis mechanism in the $\mathrm{Ti}-\mathrm{Al}-\mathrm{C}$ system revealed that grains of $\mathrm{TiC}$ precipitated first from the melt, and the $\mathrm{Ti}_{3} \mathrm{AlC}_{2}$ phase (binder) crystallized later, when temperature decreased below 1633 K [34]. Similarly, we can assert that after solid TiC grains precipitated from the melt as the primary product (Fig. 5) in the TiC-CoCrFeNiAl system, no excessed $\mathrm{Ti}$ remained in the melt to react with $\mathrm{TiC}$ and form MAX-phases. However, formation of MAX phases may become possible if we add some excess of Ti to this system. 


\section{Conclusions}

Ceramic-metal composites consisting of TiC-high entropy alloy (HEA) were produced, for the first time, by combustion synthesis (self-propagating high-temperature synthesis). Self-sustained synthesis occurs due to the heat released from the exothermic reaction $\mathrm{Ti}+\mathrm{C}=\mathrm{TiC}$ and propagates across the samples in the form of solid combustion wave. Simultaneously, five elemental metal powders undergo melting in the combustion wave and yield multicomponent liquid solution $\mathrm{CoCrFeNiMe}(\mathrm{Me}=\mathrm{Mn}, \mathrm{Ti}$ or $\mathrm{Al}$ ) that crystallizes into HEA as a binder phase behind the wave. A binder content can be varied from zero up to $40-50 \mathrm{wt} . \%$. The combustion velocity and temperature gradually decrease with increasing amount of binder.

XRD and SEM results show that all synthesized materials consist of TiC grains and two-phase ( $f c c$ and $b c c)$ metallic binder. The Vickers microhardness (100 g) of the compacted cermet materials with $30 \mathrm{wt} \%$ of binder is in the range $10 \mathrm{GPa}-17 \mathrm{GPa}$, increasing with an increase in a $b c c$ to $f c c$ ratio.

\section{Acknowledgements}

This work was supported by Russian Foundation for Basic Research, project No. 18-5315006 (in the frame of International Russian-French Program RFBR-CNRS). The authors gratefully acknowledge the financial support of the Ministry of Science and Higher Education of the Russian Federation in the framework of Increase Competitiveness Program of NUST «MISiS» (№ K2-2018-013), implemented by a governmental decree dated 16th of March 2013, N 211, that allowed utilization of 
modern techniques of the samples preparation and testing. We thank Mrs. Aleftina

Belikova for microhardness measurements.

\section{References}

[1] A. Rajabi, M.J. Ghazali, J. Syarif, A.R. Daud, Development and application of tool wear: A review of the characterization of TiC-based cermets with different binders. Chem. Eng. J. 255 (2014) 445-452. http://dx.doi.org/10.1016/j.cej.2014.06.078

[2] A. Rajabi, M.J. Ghazali, A.R. Daud, Chemical composition, microstructure and sintering temperature modifications on mechanical properties of TiC-based cermet - A review. Mater. Design 67 (2015) 95-106.

http://dx.doi.org/10.1016/j.matdes.2014.10.081

[3] Y. Peng, H. Miao, Z. Peng, Development of TiCN-based cermets: Mechanical properties and wear mechanism. Int. J. Refract. Met. H. Materials 39 (2013) 78-89. doi:10.1016/j.ijrmhm.2012.07.001

[4] J.-W. Yeh, S.-K. Chen, S.J. Lin, J.-Y. Gan, T.-S. Chin, T.-T. Shun, C.-H. Tsau, S.-Y. Chang, Nanostructured high-entropy alloys with multiple principal elements: Novel design concepts and outcomes. Adv. Eng. Mater. 6 (2004) 299-303.

[5]. B. Cantor, Multicomponent and high entropy alloys. Entropy 16 (2014) 4749-4768. https://doi.org/10.3390/e16094749.

[6] J.-W. Yeh, Physical metallurgy of high-entropy alloys. JOM 67(10) (2015) 2254-2261. DOI: 10.1007/s11837-015-1583-5.

[7] B.Cantor, I.T.H. Chang, P. Knight, A.J.B. Vincent, Microstructural development in equiatomic multicomponent alloys. Mater. Sci. Eng. A 375-377 (2004) 213-218. doi:10.1016/j.msea.2003.10.257.

[8] B. Gludovatz, A. Honenwarter, D. Catoor, E.H. Chang, E.P. George, R.O. Ritchie, A fracture-resistant high-entropy alloy for cryogenic applications. Science 345 (2014) 1153-1158. DOI: $10.1126 /$ science. 1254581 .

[9] Z.J. Zhang, M.M. Mao, J. Wang, B. Gludovatz, Z. Zhang, S.X. Mao, E.P. George, Q. Yu, R.O. Ritchie, Nanoscale origins of the damage tolerance of the high-entropy alloy CrMnFeCoNi. Nature Comm. 6 (2015) 10143(1-6). DOI: 10.1038/ncomms10143.

[10] I.L. Velo, F.J. Gotor, M.D. Alcala, C. Real, J.M. Cordoba, Fabrication and characterization of WC-HEA cemented carbide based on the CoCrFeNiMn high entropy alloy. Journal of Alloys and Compounds 746 (2018) 1-8. https://doi.org/10.1016/j.jallcom.2018.02.292

[11] G. Zhu, Y. Liu, J. Ye, Fabrication and properties of Ti(C,N)-based cermets with multicomponent AlCoCrFeNi high-entropy alloys binder. Mater. Lett. 113 (2013) 80-82. http://dx.doi.org/10.1016/j.matlet.2013.08.087 
[12] G. Zhu, Y. Liu, J. Ye, Early high-temperature oxidation behavior of Ti(C,N)-based cermets with multi-component $\mathrm{AlCoCrFeNi}$ high-entropy alloy binder. Int. J. Refract. Met. H. Materials 44 (2014) 35-41. http://dx.doi.org/10.1016/j.ijrmhm.2014.01.005

[13] W. Ji, J. Zhang, W. Wang, H. Wang, F. Zhang, Y. Wang, Z. Fu, Fabrication and properties of $\mathrm{TiB}_{2}$-based cermets by spark plasma sintering with $\mathrm{CoCrFeNiTiAl} \mathrm{high-entropy} \mathrm{alloy} \mathrm{as}$ sintering aid. J. Europ. Ceram. Soc. 35 (2015) 879-886. http://dx.doi.org/10.1016/j.jeurceramsoc.2014.10.024

[14] Z. Fu, R. Koc, Ultrafine TiB2-TiNiFeCrCoAl high-entropy alloy composite with enhanced mechanical properties. Mater. Sci. Eng. A 702 (2017) 184-188.

http://dx.doi.org/10.1016/j.msea.2017.07.008

[15] S. Zhang, Y. Sun, B. Ke, Y. Li, W. Ji, W. Wang, Z. Fu, Preparation and characterization of $\mathrm{TiB}_{2}$-(Supra-Nano-Dual-Phase) high-entropy alloy cermet by spark plasma sintering. Metals 8 (2018) 58(1-10). doi:10.3390/met8010058

[16] Z. Fu, R. Koc, TiNiFeCrCoAl high-entropy alloys as novel metallic binders for $\mathrm{TiB}_{2}-\mathrm{TiC}$ based composites. Mater. Sci. Eng. A 735 (2018) 302-309.

https://doi.org/10.1016/j.msea.2018.08.058

[17] A.G. de la Obra, M.A. Avilés, Y. Torres, E. Chicardi, F.J. Gotor, A new family of cermets: Chemically complex but microstructurally simple. Int. J. Refract. Met. H. Materials 63 (2017) 17-25. http://dx.doi.org/10.1016/j.ijrmhm.2016.04.011

[18] A.G. Merzhanov, Self-propagating high-temperature synthesis: Twenty years of research and findings, in: Z. Munir, J.B. Holt (Eds.), Combustion and Plasma Synthesis of HighTemperature Materials, VCH, New York, 1990, pp. 1-53.

[19] I.P. Borovinskaya, E.A. Levashov, STIM alloys, in: I.P. Borovinskaya, A.A. Gromov, E.A. Levashov, Yu.M. Maksimov, A.S. Mukasyan, A.S. Rogachev (Eds.), Concise encyclopedia of self-propagating high-temperature synthesis, Elsevier, 2017, pp. 364-365. ISBN: 978-0-12804173-4.

[20] E.A. Levashov, A.S. Mukasyan, A.S. Rogachev, D.V. Shtansky, Self-propagating hightemperature synthesis of advanced materials and coatings. Int. Mater. Rev. 62 (2017) 203-239. DOI: 10.1080/09506608.2016.1243291.

[21] A.S. Rogachev, A.S. Mukasyan, Combustion for Material Synthesis; CRC Press Taylor \& Francis Group, 2015. ISBN: 978-1-4822-3951-5.

[22] A. Rogachev, S. Vadchenko, A. Nepapushev, A. Sedegov, N. Kochetov, A. Gryadunov, Yu. Vergunova, F. Baras, O. Politano, A. Fourmont, S. Le Gallet, Mechanical activation for synthesis of ceramics and high entropy alloys. In: Advanced research workshop "Engineering Ceramics 2019 Ceramics for people", Smolenice castle, Slovakia, May 12-16, 2019, book of abstracts, p. 13.

[23] A.S. Rogachev, A.N. Gryadunov, N.A. Kochetov, A.S. Shchukin, F. Baras, O. Politano, High-entropy-alloy binder for TiC-based cemented carbide by SHS method. Int. J. Self-Prop. High-Temp. Synthesis 28 (2019) 196-198. doi:10.3103/S1061386219030117

[24] V.N. Lipatnikov, L.V. Zueva, A.I. Gusev, A. Kottar, Disorder-order phase transformations and electrical resistivity of nonstoichiometric titanium carbide. Phys. Solid State 40 (1998) 1211-1218. https://doi.org/10.1134/1.1130523 
[25] K.-Y. Tsai, M.-H. Tsai, J.-W. Yeh, Sluggish siffusion in Co-Cr-Fe-Mn-Ni high-entropy alloys. Acta Mater. 61 (2013) 4887-4897. http://dx.doi.org/10.1016/j.actamat.2013.04.058.

[26] M. Vaidya, S. Trubel, B.S. Murty, G. Wilde, S.V. Divinski, Ni tracer diffusion in CoCrFeNi and CoCrFeMnNi high entropy alloys. J. Alloys Compd. 688B (2016) 994-1001. DOI: 10.1016/j.jallcom.2016.07.239.

[27] F. Prusa, A. Senkova, V. Kucera, J. Capek, D. Vojtech, Properties of high-strength ultrafine-grained $\mathrm{CoCrFeNiMn}$ high-entropy alloy prepared by short-term mechanical alloying and spark plasma sintering. Mater. Sci. Eng. A 734 (2018) 341-352.

https://doi.org/10.1016/j.msea.2018.08.014

[28] L.R. Owen, E.J. Pickering, H.Y. Playford, H.J. Stone, M.G. Tucker, N.G. Jones, An assessment of the lattice strain in the CrMnFeCoNi high-entropy alloy. Acta Mater. 122 (2017) 11-18. http://dx.doi.org/10.1016/j.actamat.2016.09.032

[29] M.A. Gutierrez, G.D. Rodriguez, G. Bozzolo, H.O. Mosca, Melting temperature of CoCrFeNiMn high-entropy alloys. Comp. Mater. Sci. 148 (2018) 69-75. https://doi.org/10.1016/j.commatsci.2018.02.032.

[30] Y. Zhang, T. T. Zuo, Z. Tang, M. C. Gao, K. A. Dahmen, P. K. Liaw, Z. P. Lu, Microstructures and properties of high-entropy alloys. Prog. Mater. Sci. 61 (2014) 1-93. http://dx.doi.org/10.1016/j.pmatsci.2013.10.001.

[31] D.B. Miracle, O.N. Senkov, A critical review of high entropy alloys and related concepts. Acta Mater. 122 (2017) 448-511. http://dx.doi.org/10.1016/j.actamat.2016.08.081.

[32] W.-C. Lee, S.-L. Chung, Ignition Phenomena and Reaction Mechanisms of the SelfPropagating High-Temperature Synthesis Reaction in the Titanium-Carbon-Aluminum System. J. Am. Ceram. Soc. 80 [1] (1997) 53-61. https://doi.org/10.1111/j.1151-2916.1997.tb02790.x.

[33] A. Zhou, C.-A. Wang, Z. Ge, L. Wu, Preparation of $\mathrm{Ti}_{3} \mathrm{AlC}_{2}$ and $\mathrm{Ti}_{2} \mathrm{AlC}$ by self-propagating high-temperature synthesis. J. Mater. Sci. Lett. 20 (2001) 1971 - 1973. DOI: 10.1023/A:1013147121618.

[34] A.S. Rogachev, J.-C. Gachon, H.E. Grigoryan, D. Vrel, J.C. Schuster, N.V. Sachkova, Phase evolution in the Ti-Al-B and Ti-Al-C systems during combustion synthesis: Time resolved study by synchrotron radiation diffraction analysis. J. Mater. Sci. 40 (2005) 2689 - 2691. DOI: 10.1007/s10853-005-2107-4. 